\title{
Tensile Properties, Biodegradability and Bioactivity of Thermoplastic Starch (TPS)/ Bioglass Composites for Bone Tissue Engineering
}

(Sifat Tegangan, Keterbiodegradan dan Kebioaktifan Komposit Kanji Termoplastik (TPS)/Biokaca untuk Kejuruteraan Tisu Tulang)

\author{
SyED NUZUL FADZLI SYED ADAM*, AZLIN FAZLINA OSMAN \& ROSLINDA SHAMSUDIN
}

\begin{abstract}
Composite fabricated from the combination of biodegradable polymer and bioactive filler is beneficial for bone tissue engineering if the biomaterial can perform similar characteristics of the natural inorganic-organic structures of bone. In this study, we have investigated the thermoplastic starch (TPS)/sol-gel derived bioglass composite as new biomaterial for bone tissue engineering. The composites were produced using selected TPS/bioglass mass ratio of 100/0, 95/5, 90/10, $85 / 15$ and 80/20 by a combination of solvent casting and salt leaching techniques. Tensile test results showed the addition of bioglass increased the tensile strength and Young's modulus, but reduced the elongation at break of the samples. The modulus of all samples were higher than the requirement for cancellous bone (10-20 MPa). The SEM imaging showed the presence of porous structure on the surface of all samples. XRD results confirmed the formation of hydroxycarbonate apatite (HCA) layer on the surface of bioglass containing samples; indicating the occurrence of surface reactions when the samples were immersed in Simulated Body Fluid (SBF). Furthermore, the presence of P-O stretch band in FTIR spectrum between 1000 and $1150 \mathrm{~cm}^{-1}$ and $\mathrm{Si}$-O-Si stretch band at $1000 \mathrm{~cm}^{-1}$ also proved the bioactivity of TPS/bioglass composite. The in vitro biodegradability analysis shows the biodegradability of TPS/bioglass composite decreases with increasing mass ratio of the bioglass.
\end{abstract}

Keywords: Bioactivity; biodegradability; bioglass; polymer composite; thermoplastic starch

\section{ABSTRAK}

Komposit yang difabrikasikan daripada gabungan polimer terbiodegradasi dan pengisi bioaktif adalah berfaedah untuk kejuruteraan tisu tulang jika bahan bio tersebut boleh menghasilkan ciri-ciri yang serupa dengan struktur inorganikorganik semula jadi tulang. Di dalam kajian ini, kami mengkaji komposit kanji termoplastik (TPS)/biokaca berasaskan sol-gel sebagai bahan bio baharu untuk kejuruteraan tisu tulang. Komposit tersebut dihasilkan mengikut nisbah berat yang terpilih iaitu 100/0, 95/5, 90/10, 85/15 dan 80/20 dengan menggunakan gabungan teknik penuangan pelarut dan larut lesap garam. Keputusan ujian tegangan mendedahkan penambahan biokaca dalam matriks TPS telah meningkatkan kekuatan tegangan dan modulus Young di samping merendahkan pemanjangan takat putus sampel. Modulus semua sampel adalah lebih tinggi daripada nilai diperlukan tulang berongga. Pengimejan SEM mendedahkan kewujudan struktur berliang di permukaan semua sampel. Keputusan XRD mengesahkan pembentukan lapisan hidroksikarbonat apatit (HCA) pada permukaan sampel mengandungi biokaca, menunjukkan berlakunya reaksi permukaan apabila sampel direndam dalam cecair badan simulasi (SBF). Tambahan pula, spektrum FTIR menunjukkan kehadiran jalur regangan $P$-O antara 1000 dan $1150 \mathrm{~cm}^{-1}$ dan jalur regangan Si-O-Si pada $1000 \mathrm{~cm}^{-1}$, juga membuktikan sifat bioaktif komposit TPS/ biokaca. Analisis keterbiodegradasian in vitro pada komposit menunjukkan keterbiodegradasian komposit TPS/biokaca berkurangan dengan peningkatan nisbah berat biokaca.

Kata kunci: Biokaca; kanji termoplastik (TPS); kebioaktifan; keterbiodegradan; komposit polimer

\section{INTRODUCTION}

Bone is a huge vascular, living and dynamic natural composite notable for its combination of mechanical strength and regenerative ability. Fractures of bone due to traumatic injury, orthopaedic surgery, or tumour removal have always been a prevalent problem in clinical orthopaedics and dentistry (Allo et al. 2012). These fractures resulting in bone defects remain a huge challenge in the field of bone tissue engineering (Jahan \& Tabrizian 2016). Although bone possesses self-regeneration ability, the size of bone fractures that can be self-regenerated, however, is limited (Martins et al. 2010). Most of the bone graft operations use autograft. However, the procedure has several drawbacks such as high operation cost, limited availability of donor source and long healing period of donor site (Laurencin et al.2006). Alternatively, allografts have been selected, yet still there were many drawbacks such as poor mechanical properties and the risk to have disease transmission (Jones et al. 2010). In order to eliminate these drawbacks, effort has been made to develop 
synthetic biomaterials that can regenerate bone as the bonegraft substitutes (Burg et al. 2000).

A wealth of studies in bone tissue engineering has been accomplished throughout the past few decades especially in developing porous biomaterials (Fu et al. 2011). The development of these synthetic biomaterials has gone through various stages from being inert, to biocompatible and now generative. Third generation biomaterial which consisting of biodegradable polymers reinforced with bioactive ceramics (bioglass or hydroxyapatite) phases are becoming increasingly desirable as they mimic the natural structure of bone (Allo et al. 2012). Third generation biomaterial in bone tissue engineering serves as an extracellular matrix (ECM) or biological scaffold for the stimulation of cell-driven tissue regeneration (Black et al. 2015). In order to serve well as scaffold, the biomaterial or the composite biomaterial should have an interconnected porous structure to enable bone tissue in-growth by allowing cellular penetration and adequate diffusion of nutrients to living cells. The waste products of the scaffold and its degraded substances also can exit the body easily through the pore without interfering surrounding tissues. With regard to this, researchers are focussing on exploiting different combination of biomaterials in order to attain high biocompatibility and optimum mechanical properties of new biocomposite with desired porous structure (Hutmacher 2001). Although numerous pre-clinical trials with different animal models have shown positive results (Cancedda et al.2007), significant issues remain due to the lack of translation into a clinical practice, including choice of biomaterial and in vitro preparation (Bao et al. 2013). This motivates the exploration of new biomaterials for use in bone tissue engineering, including the biopolymers such as thermoplastic starch (TPS). TPS is produced from natural source, and thus biodegradable. Biodegradable materials have attracted much interest in bone tissue engineering, especially for scaffold application because no more surgery required to remove the scaffold from the body after the implantation surgery. This type of composite scaffold will degrade and therefore allow the human cells to produce new bone and replace the degraded scaffold (Allo et al. 2012; Jahan \& Tabrizian 2016).

In this work, the use of TPS as the matrix material was inspired by the natural origin of this material, its renewability, low cost, biodegradability, biocompatibility and tailorable physical and mechanical properties. The incorporation of bioglass as filler is anticipated to further enhance the mechanical properties and bioactivity of the host TPS to be more viable which possess biodegradability, bioactivity and feasibility adaptable for advanced tissue engineering application.

\section{MATERIALS AND METHODS}

Bioglass powder used in this study is based on $50 \%$ $\mathrm{SiO}_{2}-42 \%$ CaO- $8 \% \mathrm{P}_{2} \mathrm{O}_{5}$ which was prepared via low temperature sol-gel processing, has high purity and bioactive. The detail procedure to prepare the bioglass powder can be assessed in our previous work. Unmodified regular corn starch, containing approximately $73 \%$ of amylopectin and $27 \%$ of amylose, was supplied by SigmaAldrich. Glycerol with the molar mass of $92.10 \mathrm{~g} / \mathrm{mol}$ was purchased from $\mathrm{HmbG}$ Chemicals. The TPS/bioglasss composites were prepared by a combination of solvent casting and salt leaching method. The solution containing 78 wt. $\%$ of deionized water, 7 wt. $\%$ of corn starch and bioglass, and 15 wt. $\%$ glycerol was heated and stirred at $85^{\circ} \mathrm{C}$ for 30 min using hot plate magnetic stirrer. Then, the gelatinized solution was cast into Teflon mould on which the salt particle (50\% of starch weight) had been poured at the bottom of the mould. Salt particles were poured onto the surface of the cast solution as well after casting. The TPS/bioglass gel was dried in $45^{\circ} \mathrm{C}$ oven for $24 \mathrm{~h}$. After drying, TPS/bioglass film was leached with deionised water for 1 day to remove salt particles that trapped inside the composite. Finally, TPS/bioglass composite film was dried at room temperature for 2-3 days prior to testing and characterization. The samples of TPS/bioglass composite were prepared at different TPS/bioglass mass ratio and assigned with different sample code as shown in Table 1.

TABLE 1. Sample code of TPS/bioglass composites at different TPS/bioglass mass ratio

\begin{tabular}{ccc}
\hline Sample code & TPS (wt. \%) & Bioglass (wt. \%) \\
\hline TB0 & 100 & 0 \\
TB5 & 95 & 5 \\
TB10 & 90 & 10 \\
TB15 & 85 & 15 \\
TB20 & 80 & 20 \\
\hline
\end{tabular}

Tensile properties of TPS/bioglass composite were assessed in accordance to ASTM Standard D638 (Type V) using Instron 5569 Universal Testing Machine. Each sample was cut into 5 dumbbell-shaped specimens and the thickness of specimens was measured by digital calliper and recorded. The testing was conducted at a constant strain rate of $5 \mathrm{~mm} / \mathrm{min}$ to determine tensile strength, Young's modulus and elongation at break of the specimens.

The main requirement for an artificial scaffold to have intimate contact with human bone is the formation of apatite (bone mineral) on its surface when embedded in the human body. This apatite formation can also be obtained if the bioactive scaffold is being immersed in a simulated body fluid (SBF) with ion concentrations nearly equal to those of human blood plasma. That means the bioactivity of the TPS/bioglass composite can be predicted through apatite formation on its surface in SBF. We have followed Kokubo protocol to test the bioactivity of the materials (Kokubo \& Takadama 2006). Generally, a bioactive material can form apatite on its surface in a short period only. For best result, the SBF shall be used within 30 days of preparation (Kokubo \& Takadama 2006). Our previous researches proved that the apatite can be further grown into bone-like apatite on the bioglass surface after 7 days of immersion 
in SBF (Fadzli et al. 2016). Therefore, we have decided to do the immersion for 14 days since our samples are composite material (where the bioglass has embedded in the TPS matrix) and might take longer time to allow clear observation of the apatite formation. The duration for this bioactivity test also tally with other researchers' work on composite scaffold, where 14 days was employed for observation of the apatite formation (Mehrali et al. 2014; Zang et al. 2008).

To perform the in vitro bioactivity test, the TPS/bioglass composite was cut into 3 specimens with the dimension of $10 \times 10 \mathrm{~mm}$ and immersed in SBF solution maintained at $37^{\circ} \mathrm{C}$ and $\mathrm{pH} 7.4$. After 14 days, specimens were removed, rinsed with deionised water and dried in $50^{\circ} \mathrm{C}$ oven for $24 \mathrm{~h}$ to ensure complete drying. The in vitro bioactivity analysis was carried by means of morphological analysis. The formation of hydroxycarbonate apatite (HCA) layer on the surface of specimens was examined by performing SEM, FTIR and XRD analysis on the dried SBF-immersed specimens.

For in vitro biodegradability test, the TPS/bioglass composite was cut into three specimens with the same weight of $30 \mathrm{mg}(\mathrm{Wi})$ and immersed in $25 \mathrm{~mL} \mathrm{sBF}$ maintained at $37^{\circ} \mathrm{C}$. After 14 days, specimens were taken out, washed with deionized water and dried in $50^{\circ} \mathrm{C}$ oven to a constant weight (Wd). The biodegradability of the samples was assessed by SEM imaging and weight loss percentage of each specimen calculated using the equation (1.0).

$$
\text { Weight loss }(\%)=\left(\mathrm{W} \_\mathrm{i}-\mathrm{W} \_\mathrm{d}\right) / \mathrm{W} \_\mathrm{i} \times 100 \%
$$

where $\mathrm{Wi}$ is the initial weight of sample; and $\mathrm{Wd}$ is the dried weight of sample.

\section{RESULTS AND DISCUSSION}

\section{TENSILE PROPERTIES}

Tensile properties of the neat TPS and TPS/bioglass composites were compared. Figure 1 shows the tensile strength, elongation at break and Young's modulus of the TPS/bioglass composites with different TPS to bioglass ratio. Based on Figure 1(a), the neat TPS possesses the lowest tensile strength amongst all. It is obvious that the addition of bioglass into TPS had significantly improved its tensile strength. The tensile strength of TPS/bioglass composite increases as the TPS/bioglass ratio change from $100 / 0$ to $80 / 20$. The findings show the highest tensile strength, $5.77 \mathrm{MPa}$, was achieved by the TB20. In fact, the tensile strength of тв20 was enhanced more than $100 \%$ compared to the тв0. The improvement of tensile strength of TPS/bioglass composite was significantly attributed by the incorporation of the glass phase, which enhance stiffness and mechanical strength of the TPS and is in accordance with previous study (Rezwan et al. 2006). Even though the tensile strength of TPS/bioglass composite samples was improved, none of the samples achieved the tensile strength requirement of cancellous bone at the range of 10-20 MPa.

However, the obtained value was impressive enough for preliminary investigation on this TPS/bioglass composite system. The TB20 composite has achieved much higher tensile strength value as compared to neat TPS, with the increment of $\sim 151 \%$. In fact, the tensile strength of TPS sample in this study was higher than the previous study of TPS sample fabricated by corn starch and glycerol which obtained the tensile strength of 3MPa (Dai et al. 2008). This shows that the addition of bioglass filler can bring significant enhancement on the mechanical strength of the TPS. Therefore, future studies will aim to further improve the tensile strength of the TPS matrix by modifying the formulation used in the plasticization process. As stated in the literature, the tensile strength of the TPS could be affected by the type and concentration of the plasticizer used (Borges et al. 2015). The optimum tensile strength could be obtained if the most suitable plasticizer was employed in an appropriate amount. This will be the main focus in our next investigation.

Figure 1(b) illustrates the elongation at break of TPS/ bioglass composite at different bioglass content. Based on the figure, the elongation at break of TPS/bioglass composite shows a decreasing trend with the increasing of bioglass content in the composite. $\mathrm{TB} 0$ shows the highest elongation at break of $15.1 \%$. The elongation at break of bioglass containing samples decreases drastically to less than $1.5 \%$ compared to pure TPS sample; and further decreases as the TPS/bioglass ratio increased. This phenomenon proved the intrinsic lack of resilience of bioglass has reduced the ductility of TPS matrix as mentioned in previous study (Dai et al. 2008). However, it can be observed that the percentage of elongation at break has reduced slightly when the bioglass filler content increased from 5 to $20 \mathrm{wt}$. \%. In contrast with the tensile strength data, elongation at break values indicate that the rigidity of TPS host polymer has not much affected by the content of the bioglass if it is added between 5 and $20 \mathrm{wt}$. \%. This is parallel with the obtained Young's modulus value of all the composite samples where only small reduction observed when the bioglass filler content increased from 5 to $20 \mathrm{wt}$. \%. However, this trend is acceptable for scaffold application because the purpose of increasing the content of bioactive filler (up to $20 \mathrm{wt}$. $\%$ ) was to enhance the tensile strength and bioactivity of the composite scaffold without causing severe reduction in its ductility in order to avoid catastrophic brittle fracture during service.

The Young's modulus of TPS/bioglass composite at different bioglass content is shown in Figure 1(c). Based on the figure, the addition of stiff bioglass into TPS matrix improves the stiffness of the composite. In general, the Young's modulus of samples was enhanced by the incorporation of bioglass filler in TPS matrix. This observation is in accordance with the finding reviewed in the article (Arjmandi et al. 2015). Concurrently, the Young's modulus of the samples continued to increase as the bioglass content in the composite increased. 

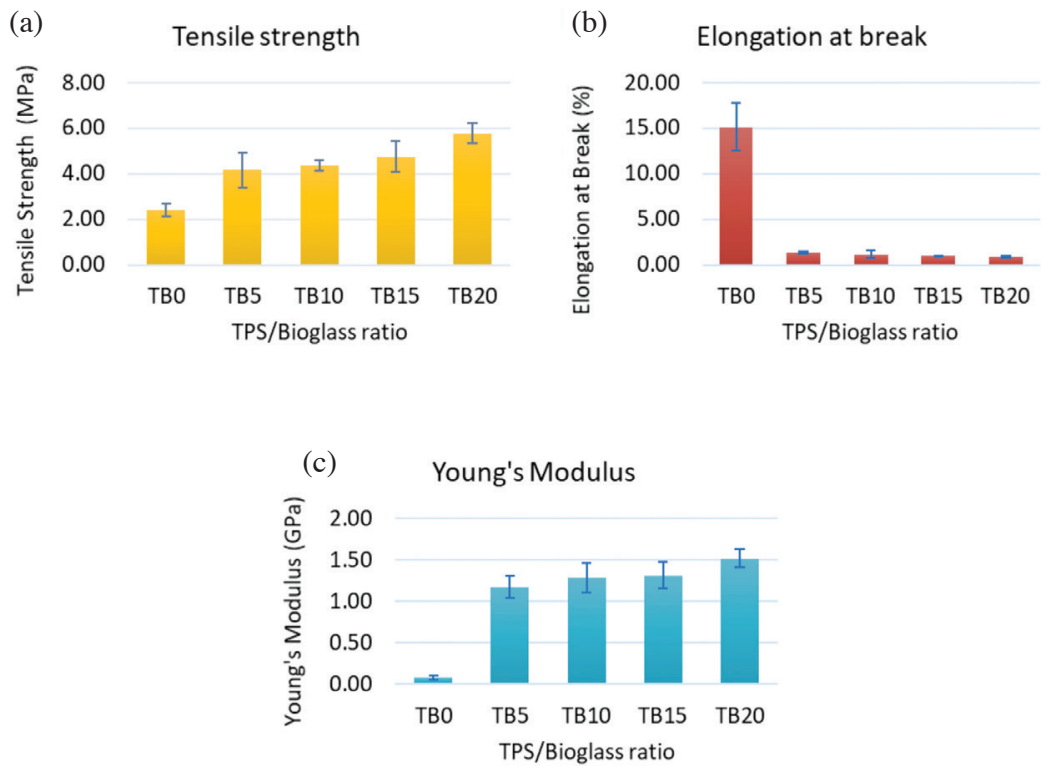

FIGURE 1. (a) Tensile strength, (b) Elongation at break and (c) Young's modulus of TPS/bioglass composites at different bioglass content

Furthermore, the results of Young's modulus of all samples were comparable to the cancellous bone at the range of 0.05 - 0.5 GPa (Hench \& Wilson 2013). TPS/Bioglass sample at weight ratio of $100 / 0,95 / 5,90 / 10,85 / 15$ and $80 / 20$ has Young's modulus of $0.08,1.17,1.28,1.31$ and $1.51 \mathrm{GPa}$, respectively, which is higher and thus stiffer compared to cancellous bone. The small standard deviations in tensile testing results of indicate the accuracy and consistency of data; suggesting that the testing procedure was correct and repeatable.

\section{FUNCTIONAL GROUP ANALYSIS}

FTIR was used to identify and study the functional groups of the bioglass, neat TPS and TPS/Bioglass composite. Figure 2 shows the FTIR spectra of the materials. The bioglass exhibits the vibration bands of silicates, $\mathrm{Si}-\mathrm{O}-\mathrm{Si}$ at 1080 and $805 \mathrm{~cm}^{-1}$, same as previously reported (Fadzli et al. 2016). The phosphates, $\mathrm{P}-\mathrm{O}$ bending vibration peaks and $\mathrm{P}-\mathrm{O}$ asymmetric stretching vibration bands were presence at 1000-1150 $\mathrm{cm}^{-1}$, respectively (Félix et al. 2011). Furthermore, $-\mathrm{OH}$ absorption band $\sim 3430 \mathrm{~cm}^{-1}$ and a weak band at $1640 \mathrm{~cm}^{-1}$ were also observed due to absorbed water. On the other hand, O-H groups (3269-3278 $\left.\mathrm{cm}^{-1}\right)$, C-H stretching (2918-2922 $\left.\mathrm{cm}^{-1}\right)$, C-C stretching (1628$\left.1639 \mathrm{~cm}^{-1}\right)$ and C-O stretching (1348-1400 $\left.\mathrm{cm}^{-1}\right)$, which corresponds to the functional groups of TPS, were shown in the FTIR spectra of neat TPS (TB0) and TPS/Bioglass composites. These findings are similar to the result reported in the literature (Ramazan Kizil \& Joseph Irudayaraj 2002). For TPS/Bioglass composite, the presence of bioglass in the TPS matrix was proven by the appearance of vibrational bands related to the phosphates $(\mathrm{P}-\mathrm{O})$ and silicates ( $\mathrm{Si}-\mathrm{O}$ $\mathrm{Si}$ ), similar with the finding reported by other researchers (Zeng \& Lace 2000). Therefore, the overlapping band between the starch and bioglass materials resulted in deeper and stronger peaks in the $800-1200 \mathrm{~cm}^{-1}$ region for all the composite samples.

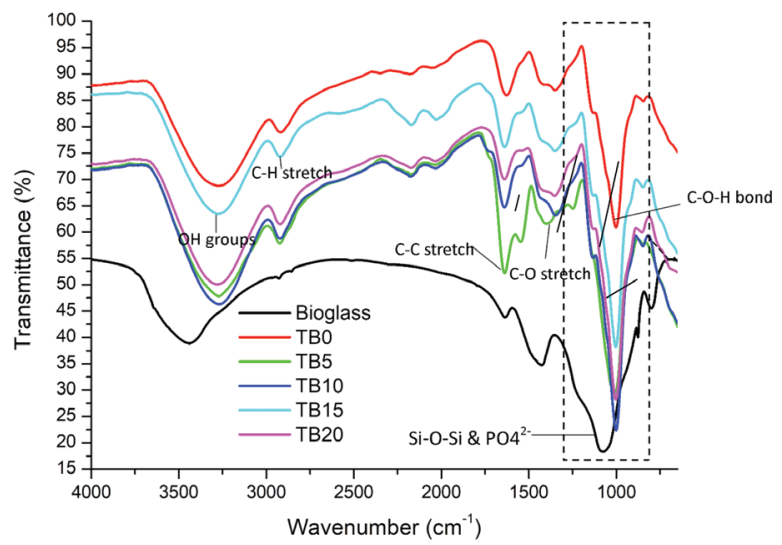

FIGURE 2. Combined IR spectra of bioglass, TPS and TPS/ bioglass composites at different bioglass content

\section{SURFACE MORPHOLOGY}

Figures 3 and 4 present the SEM images of TPS/bioglass composites containing 5,10,15 and $20 \mathrm{wt}$. \% bioglass at high magnification (10000X) before and after the SBF immersion, respectively. Based on the micrographs obtained, all the samples exhibit uneven porous structures as shown in Figure 3. These porous structures were formed when salt particles were leached out from the samples during salt leaching step. This finding suggests that the salt leaching process needs to be controlled/ improved in future study to obtain an even and interconnected porous/scaffold-like structure. In general, apatite-like structure were formed on the surface of these composite after 14 days as shown in Figure 4. The 
deposition of these apatite-like structure can be observed on the surface of these composites. These apatite-like structure was also similarly observed as in previous study (Fadzli et al. 2016). For тв10 and тв15, particulate apatite were deposited after the immersion. However, when higher loading of bioglass was used (20 wt. \%), the bioactivity of the host TPS was enhanced, in which more stable apatite-like struture (in layered form) was formed. This HCA layers can be clearly observed in TB20 sample, which indicates an increased in the in vitro bioactivity property of composite samples with the increasing of bioglass content.
PHASE ANALYSIS

Figure 5 shows the XRD pattern of TPS/bioglass composite samples after immersed in SBF for 2 weeks. Bioglass typically showed a broad XRD pattern due to its amorphous phase (Fadzli et al. 2016). As mentioned earlier, apatiteforming ability of a material upon immersion in SBF can be used to predict its bioactivity (Fadzli et al. 2016; Kokubo \& Takadama 2006). Less apatite formation means less bioactivity. Based on XRD analysis, the apatite-related diffraction peaks can be observed at $2 \theta$ of $26^{\circ}$ and $31.7^{\circ}$. These two peaks were assigned to the (002) and (211) lattice planes of apatite according to the Joint Committee
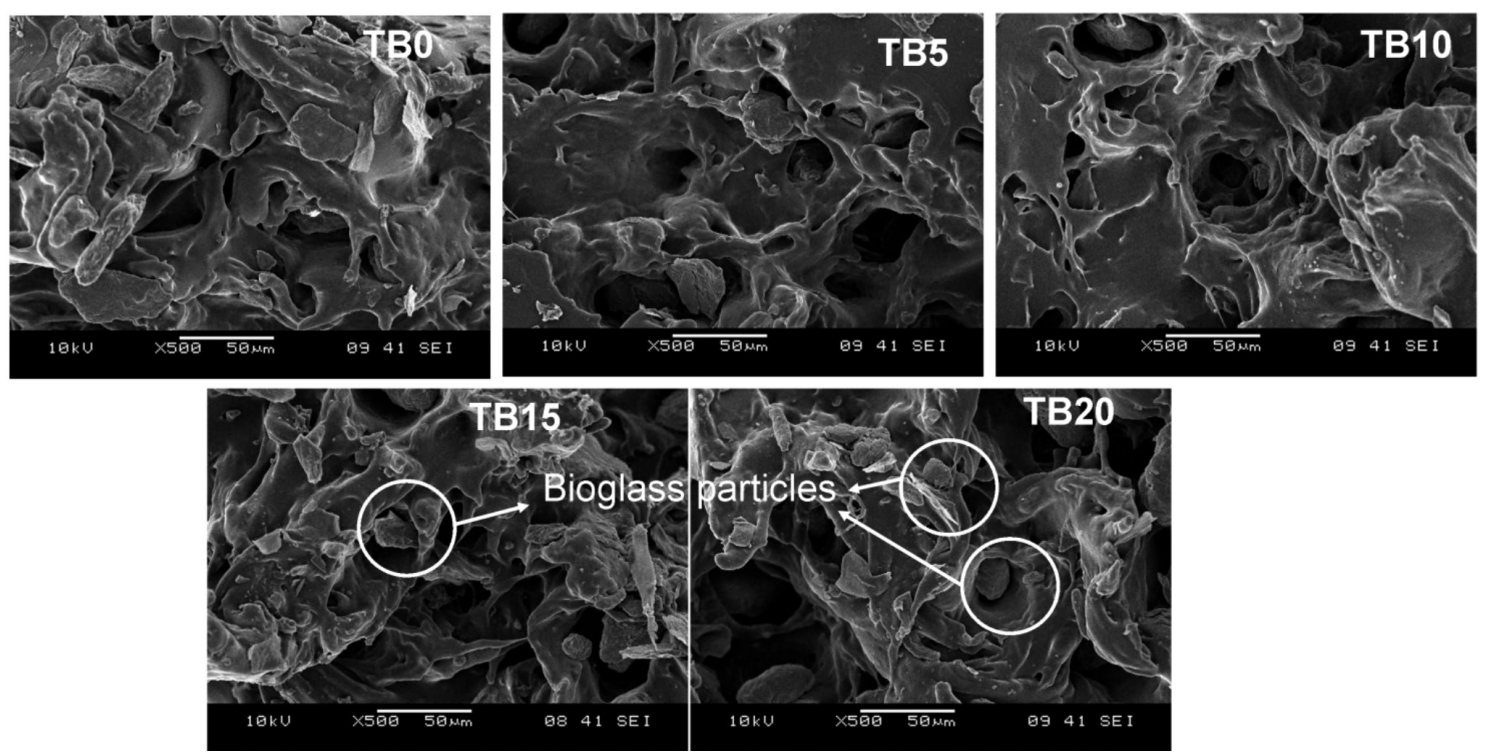

FIGURE 3. Surface morphology of neat TPS and TPS/bioglass composites by SEM analysis before the SBF immersion
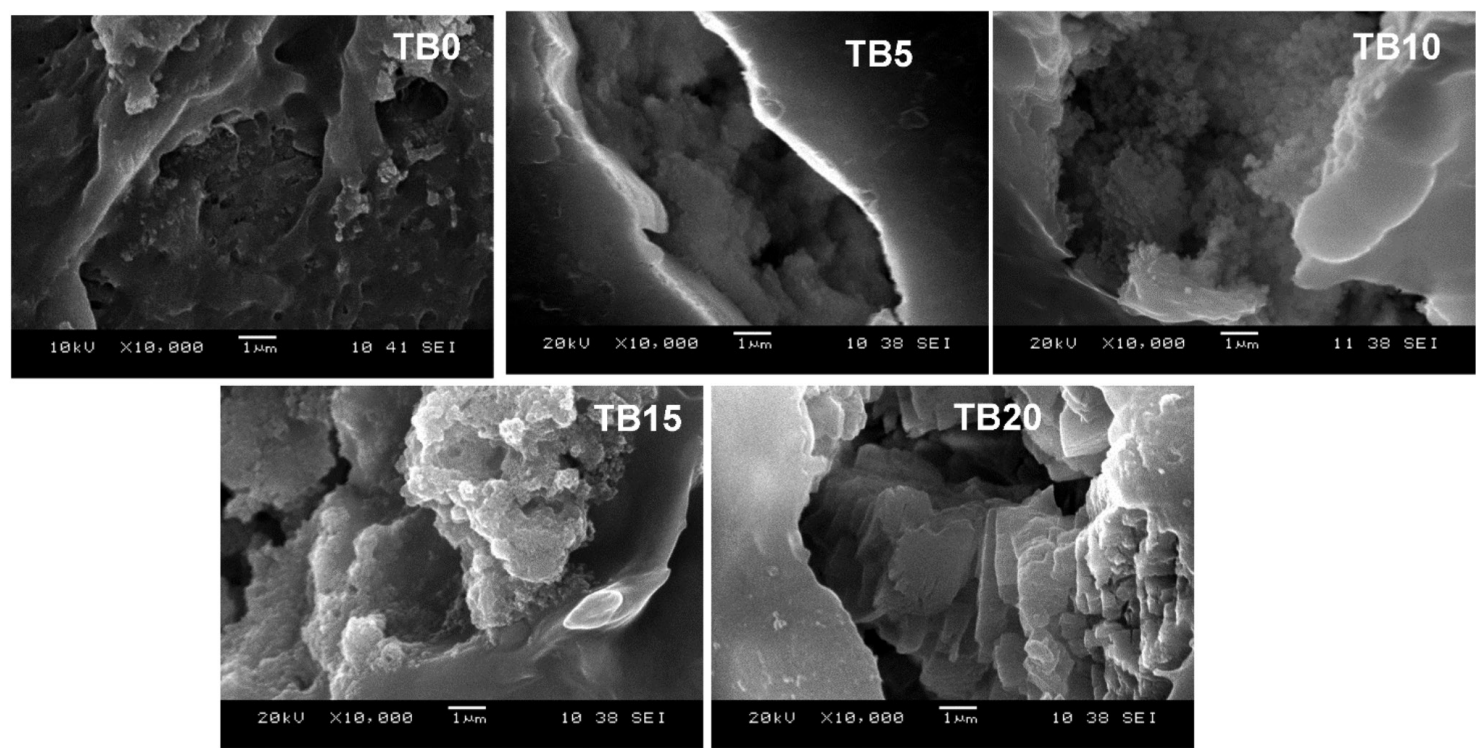

FIGURE 4. The surface morphology of neat TPS and TPS/bioglass composites (after SBF immersion) showing the HCA layers can be most clearly observed in TB20 
on Powder Diffraction Standards (JCPDS file No. 090432), respectively (Xu et al. 2015). Figure 5 illustrates that all SBF immersed TPS/Bioglass composite samples have apatite deposited on the sample surface. However, there was no apatite-related diffraction peaks in the diffraction pattern of neat TPS (ТВ0) as no bioglass was added into this sample. This indicates that, TPS sample without the bioglass content not showing any in vitro bioactive property when immersed in SBF solution. Apart of that, broad peak in XRD pattern of TВ0 sample, represents the amorphous structure of TPS.

TPS with higher content of bioglass (ТВ10, ТВ15 and тв20) showed more intense peak at $2 \theta$ of $26^{\circ}$ and $31.7^{\circ}$, indicating the increasing amount of deposited apatite on the surface of the samples. This suggests that TPS with low content of bioglass (ТВ5) possessed less bioactivity due to fewer degree of apatite formation on its surface as detected through its weaker apatite-related diffraction peaks. This study shows that, by adding the bioglass into the TPS matrix for $20 \mathrm{wt} . \%$, the bioactivity of the TPS matrix can be significantly increased. The results also are in good agreement with the SEM analysis (Figure 3). Besides, the resulting characteristic peaks narrow significantly with the increasing bioglass content, showing the increasing in the crystallinity of the apatite layer formed at the surface of these samples.

\section{IN VITRO BIODEGRADABILITY}

In vitro biodegradability analysis on the TPS/bioglass composites was performed in SBF solution $\left(\mathrm{pH} 7.4,37^{\circ} \mathrm{C}\right)$.
Figure 6 depicts the weight loss of TPS/Bioglass composite at different weight ratio. All samples experienced weight loss after 2 weeks of immersion in SBF. The results showed a decreasing trend in weight loss with increasing bioglass content. As predicted, the degradation rate of TPS in SBF has decreased due to low degradation rate of bioglass. Neat TPS (ТВ0) exhibits the highest weight loss of $61.11 \%$, followed by тв5, тв10, тв15 and тв20 with weight loss of $56.67 \%, 51.11 \%, 33.33 \%$ and $32.22 \%$, respectively. The weight loss in ТВ0 was mainly caused by the separation of glycerol among the starch chains out of the sample during degradation in SBF. The cleavage of the linkages of glycerol resulted in the destruction of crystallinity of pure TPS sample during degradation (Shi et al.2006). This phenomenon was proven by the broad peak in XRD pattern of sample тв0, which represents the amorphous structure, as shown in Figure 5. On the other hand, sudden drop of weight loss between ТВ10 and ТВ15 may attributed to the significant increased in HCA layer formation at the surface of the samples.

\section{CONCLUSION}

In conclusion, this study demonstrates that the addition of bioglass in TPS matrix improved the tensile properties, biodegradability and bioactivity of the TPS/bioglass composite. The increasing in bioglass weight fraction in TPS/bioglass composite leads to the enhancement in tensile strength, modulus and in vitro bioactivity of the

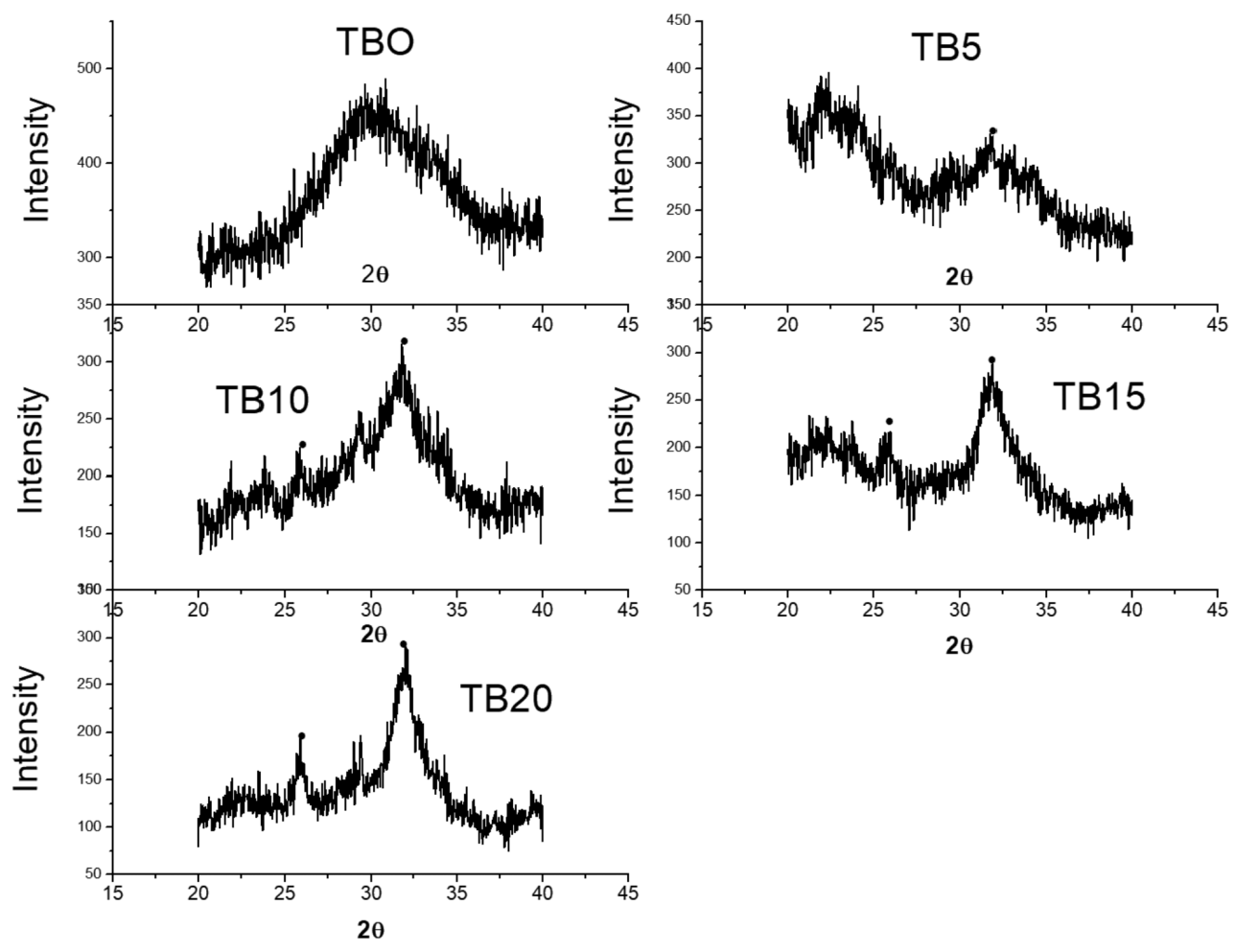

FIGURE 5. XRD pattern of TPS/bioglass composite samples after two weeks immersion in SBF solution 


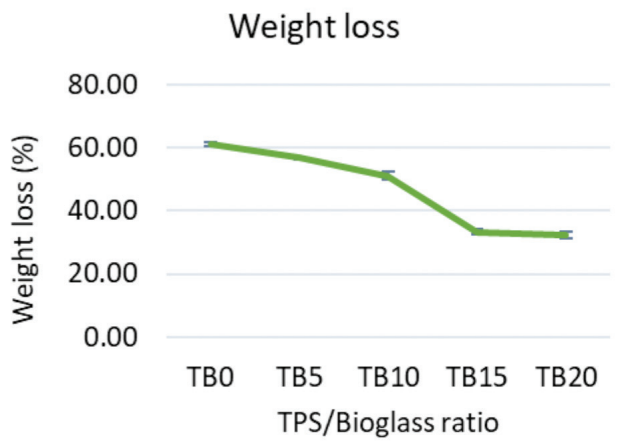

FIGURE 6. Percentage of weight loss of the TPS/bioglass composites after 2 weeks of SBF immersion

composite; but at the same time, reduces the ductility and in vitro biodegradability of the composite. However, further enhancement of inter-connected porous structure in the TPS/bioglass composite morphology is needed to obtain feasible scaffold for bone tissue engineering. The bioglass added into TPS should be reduced to 1-4 due to 5 wt. \% have dramatically increase the mechanical properties of this tissue engineering scaffold.

\section{ACKNOWLEDGEMENTS}

The authors would like to thank Pan Hui Qi and Siti Rohani Zainudin (MSc. students of School of Materials Eng, UniMAP) for their kind help including in SBF solution preparations and in vitro bioactivity test.

\section{REFERENCES}

Allo, B.A., Costa, D.O., Dixon, S.J., Mequanint, K. \& Rizkalla, A.S. 2012. Bioactive and biodegradable nanocomposites and hybrid biomaterials for bone regeneration. Journal of Functional Biomaterials 3(4): 432-463.

Arjmandi, R., Hassan, A., Majeed, K. \& Zakaria, Z. 2015. Rice husk filled polymer composites. International Journal of Polymer Science 2015. Article ID. 501471.

Bao, C.L.M., Teo, E.Y., Chong, M.S.K., Liu, Y., Choolani, M. \& Chan, J.K.Y. 2013. Advances in bone tissue engineering. In Regenerative Medicine and Tissue Engineering (Book Chapter), edited by Andrades, J.A. www.intechopen.com. pp. 599-614.

Black, C.R.M., Goriainov, V., Gibbs, D., Kanczler, J., Tare, R.S. \& Oreffo, R.O.C. 2015. Bone tissue engineering. Current Molecular Biology Reports 3: 132-140.

Borges, J.A., Romani, V.P., Cortez-Vega, W.R. \& Martins, V.G. 2015. Influence of different starch sources and plasticizers on properties of biodegradable films. International Food Research Journal 22(6): 2346-2351.

Burg, K.J., Porter, S. \& Kellam, J.F. 2000. Biomaterial developments for bone tissue engineering. Biomaterials 21(23): 2347-2359.

Cancedda, R., Giannoni, P. \& Mastrogiacomo, M. 2007. A tissue engineering approach to bone repair in large animal models and in clinical practice. Biomaterials 28(29): 4240-4250.

Dai, H., Chang, P.R., Yu, J. \& Ma, X. 2008. N,N-Bis(2hydroxyethyl)formamide as a new plasticizer for thermoplastic starch. Starch 60(12): 676-684.
Fadzli, S.A.S.N., Roslinda, S., Zainuddin, F. \& Ismail, H. 2016 Synthesis of sol-gel derived glass powder and in vitro bioactivity property tested in simulated body fluid. AIP Conference Proceedings 1784 Art. No: 040033.

Félix, A., Almeida, E. De, Cristina, E. \& Ortega, A. 2011. Synthesis of chitosan/hydroxyapatite membranes coated with hydroxycarbonate apatite for guided tissue regeneration purposes. Applied Surface Science 257: 3888-3892.

Fu, Q., Saiz, E., Rahaman, M.N. \& Tomsia, A.P. 2011. Bioactive glass scaffolds for bone tissue engineering: State of the art and future perspectives. Materials Science \& Engineering C 31(7): 1245-1256.

Hench, L.L. \& Wilson, J. 2013. An Introduction to Bioceramics. 2nd ed. London: Imperial College Press.

Hutmacher, D.W. 2001. Scaffold design and fabrication technologies for engineering tissues - state of the art and future perspectives. Journal of Biomaterials Science, Polymer Edition 12(1): 107-124.

Jahan, K. \& Tabrizian, M. 2016. Composite biopolymers for bone regeneration enhancement in bony defects. Biomaterial Science 4(1): 25-39.

Jones, J.R., Lin, S., Yue, S., Lee, P.D., Hanna, J.V., Smith, M.E. \& Newport, R.J. 2010. Bioactive glass scaffolds for bone regeneration and their hierarchical characterisation. Proceeding Inst. Mech. Eng. H. 224: 1373-1387.

Kokubo, T. \& Hiroaki Takadama, H. 2006. How useful is SBF in predicting in vivo bone bioactivity? Biomaterials 27 : 2907-2915.

Laurencin, C., Khan, Y., Kofron, M., Al-Amin, S., Botchwey, E., Yu, X. \& Cooper, J.J. 2006. The ABJS Nicolas Andry Award: Tissue engineering of bone and ligament: A 15-year perspective. Clinical Orthopaedics and Related Research 447: 221-236.

Martins, A.M., Alves, C.M., Kasper, F.K., Mikos, A.G. \& Reis, R.L. 2010. Responsive and in situ-forming chitosan scaffolds for bone tissue engineering applications: An overview of the last decade. Journal of Materials Chemistry 20: 1638-1645.

Mehrali, M., Moghaddam, E. \& Seyed Shirazi, S.F. 2014. Mechanical and in vitro biological performance of graphene nanoplatelets reinforced calcium silicate composite. PLOS ONE 9(9): e106802.

Ramazan, K. \& Joseph Irudayaraj, K.S. 2002. Characterization of irradiated starches by using ft-Raman and FTIR spectroscopy. Agriculture and Food Chemistry 50: 3912-3918.

Rezwan, K., Chen, Q.Z., Blaker, J.J. \& Roberto, A. 2006. Biodegradable and bioactive porous polymer / inorganic composite scaffolds for bone tissue engineering. Biomaterials 27: 3413-3431.

Shi, R., Ding, T., Liu, Q. \& Han, Y. 2006. In vitro degradation and swelling behaviour of rubbery thermoplastic starch in simulated body and simulated saliva fluid and effects of the degradation products on cells. 91. Polymer Degradation and Stability 91(12): 3289-3300.

Xu, J., Liu, L. \& De, Z.X. 2015. Promoting bone-like apatite formation on titanium alloys through nanocrystalline tantalum nitride coatings. Journal of Materials Chemistry B 3: 4082-4094.

Zeng, H. \& Lace, W.R. 2000. XPS, EDX and FTIR analysis of pulsed laser deposited calcium phosphate bioceramic coatings: The effects of various process parameters. Biomaterial 21: 23-30. 
Syed Nuzul Fadzli Syed Adam* \& Roslinda Shamsudin School of Applied Physics

Faculty of Science and Technology

Universiti Kebangsaan Malaysia

43600 UKM Bangi, Selangor Darul Ehsan

Malaysia

\section{Azlin Fazlina Osman}

Center of Excellence Geopolymer and Green Technology (CEGeoGTech)

School of Materials Engineering

Universiti Malaysia Perlis (UniMAP)

02600 Jejawi, Arau, Perlis Indera Kayangan

Malaysia
*Corresponding author: syed.nuzul@unimap.edu.my

Received: 3 October 2017

Accepted: 26 January 2018 